\title{
Exit Strategy to Ease or Eliminate Tax Responses to the COVID-19 Pandemic
}

\author{
Tapas K. Sen ${ }^{1}$
}

This governance brief was prepared by Tapas K. Sen in coordination with Bruno Carrasco, Director General of the Sustainable Development and Climate Change Department; Go Nagata, Public Management Specialist (Taxation); and Daisuke Miura, Public Management Specialist (Taxation) from the Asian Development Bank (ADB). Hiranya Mukhopadhyay, Principal Public Management Specialist, served as an ADB peer reviewer with Annette Chooi and Richard Highfield, ADB consultants specializing in taxation. The author would like to thank Chinmay Pant for his substantive help in preparing this brief.

\section{Executive Summary}

This brief focuses on tax stimuli provided by nations in the Asia and Pacific region in the aftermath of the coronavirus disease (COVID-19) pandemic and the lockdowns and other restrictions; these were designed to pull economies out of the subsequent recession. Using illustrative cases, it examines the type and design of tax stimulus introduced and estimates overall tax losses and losses attributable to tax measures, and the risks associated with such measures. It then discusses issues related to an exit from the tax incentives provided-the what, when, and how - in the context of budgetary considerations and the costs of recession. The brief also provides detailed guidelines on an appropriate strategy in terms of identification of timing and the choice between a staggered or simultaneous exit, keeping in mind that circumstances differ between countries and each must tailor its strategy accordingly. It draws on existing literature and maps a way forward by articulating the steps and inputs needed for planning an exit. Recommendations are offered on specific tax measures for exit processes and the post-exit stage. The brief was sponsored by the Domestic Resource Mobilization Trust Fund of the Asian Development Bank (ADB) with a contribution from the Government of Japan.

\footnotetext{
Tapas K. Sen, is associated with PricewaterhouseCoopers India as advisor (Government Reforms and Infrastructure Development). He was a member of the faculty of the National Institute of Public Finance and Policy in New Delhi, India, from 1981 to 2016. He has worked on aspects of public finance and published numerous monographs, reports, papers, and other publications. He has been a consultant on behalf of his employers and in his individual capacity to the World Bank, ADB, the United Nations Development Programme, the European Commission, DFID (UK), and CIDA (Canada). He also provided research inputs to the Government of India at both national and subnational levels and has been a member of official study groups, working groups, and committees.
} 


\section{Introduction}

\section{Tax Measures as Part of a Policy to Mitigate the Economic Impact of COVID-19}

The coronavirus disease (COVID-19) pandemic has adversely affected people everywhere and caused economic hardship for communities, consumers, and businesses across the globe. As the pandemic continues to keep several industries tottering, the situation is alarming for some businesses affected disproportionately by lockdowns of various lengths implemented by different nations to contain the outbreak. Governments have been providing various economic relief and recovery packages for mitigating disruptions and economic impacts. These packages comprise both fiscal and monetary measures to support businesses, households, and workers. Although the economic response varies depending on country-specific circumstances, one measure that seems common across jurisdictions is a combination of tax concessions.

Tax policy measures were expected to play an important role in providing relief to businesses when economic activities were disrupted because of the lockdowns imposed by governments. These measures varied from immediate to long-term measures such as extension of tax filing deadlines, tax deferrals, direct and indirect reductions in effective business tax rates, temporary and permanent tax deductions, tax waivers, and enhanced tax loss provisions. While relief and immediate recovery measures are short-term and temporary, long-term measures are meant to counter relatively lasting damage to the economy resulting from the pandemic (e.g., to growth prospects).

Timely adoption and execution of immediate and long-term crisis response tax measures have provided relief to businesses in the form of help in maintaining cash flows for meeting liquidity, working capital and other related requirements. Economists have argued that tax measures are imperative to provide cash flow support to businesses and individuals during and after the peak of the crisis, but over the long term, continuing tax concessions can adversely affect public finances. ${ }^{2}$ Finding the optimal balance is important.

\section{The rationale for fiscal packages as public interventions}

The lockdowns imposed by various governments to contain the pandemic brought much of the world's economic activity to a standstill. In the aftermath of lockdowns, economies witnessed sudden and profound economic impacts including business shutdowns, job losses, shrinking household incomes, reduced production, stressed medium and small industrial and service sector units, solvency risks, and supply shocks. Sustained efforts are required to foster recovery from a pandemic-induced recession. These include public interventions in the form of fiscal stimuli to support consumption and investments to bolster demand and supply sides. Comprehensive fiscal packages not only ensure sustained liquidity measures to support industries to meet their daily business needs but also provide income support to households adversely affected by disruptions. These packages provide both immediate and longterm incentives and help push economies onto the path of economic recovery and sustainability.

\section{Elements and objectives of fiscal interventions}

An effective fiscal stimulus package may have diverse elements depending on the challenges a country faces in supporting businesses and households. These elements comprise measures including but not limited to direct cash transfers, augmenting unemployment benefits, tax reductions and deferrals, business investment incentives, and government spending measures. The ultimate objective of these interventions is to provide cash flow and income support to businesses and households, and incentives to invest and raise production. The literature suggests that for a fiscal intervention to be effective, it must be timely and targeted (sections 5 and 6). Only then can they reach the most affected beneficiaries quickly and help ensure continuity of production and consumption spending. Although countries have adopted different fiscal packages, a combination of interventions in tax policy and administration is a common element in most.

Given the importance of tax stimuli in the fiscal packages for relief and recovery, the focus of this brief

\footnotetext{
2 For example, the Organisation of Economic Co-operation and Development (OECD) describes four stages of pandemic attack and containment, and four corresponding stages of tax policy requirements (liquidity and income support, maintaining solvency, providing stimulus, and raising revenues in the post-pandemic situation). See OECD. 2020. Tax and Fiscal Policy in Response to the Coronavirus Crisis: Strengthening Confidence and Resilience. http://www.oecd.org/ctp/tax-policy/tax-and-fiscalpolicy-in-response-to-the-coronavirus-crisis-strengthening-confidence-and-resilience.htm.
} 
is on an important aspect of these interventionspolicy considerations for an exit strategy for economic stimulus in the form of tax incentives such as tax relief and tax deferrals. The section following this introduction reviews the impact of COVID-19 on tax revenues in selected countries in the Asia and Pacific region and assesses the asymmetric impact on business sectors. Tax policy responses by the selected countries are reviewed in the third section. The fourth section provides estimates of the cost of tax measures in some countries. The fifth section discusses a priori considerations for working out a general strategy for exiting from tax stimuli. The sixth section deals with risks associated with tax interventions and the final section concludes with recommendations for a way forward.

\section{Impact of COVID-19 on} Tax Revenues: A Selective Review of Countries in the Asia and Pacific Region

\section{Overall Impact on Revenue Collections}

The COVID-19 crisis adversely impacted tax revenue collections in the Asia and Pacific region. The data on tax revenue reported for the first few months of the calendar year indicate a substantial fall in tax revenues across the region. For example, countries in the relatively more developed East Asian region witnessed sharp contractions in tax revenues. Japan's tax revenues dropped $29.4 \%$ in April 2020, which was the biggest monthly year- on-year decline since 2009. Similarly, in the People's Republic of China (PRC) tax revenues plummeted by $16.4 \%$ in the first quarter of 2020 (January-March) on a year-on-year basis. ${ }^{4}$ The Republic of Korea's tax revenues for the first quarter of 2020 (JanuaryMarch) fell by approximately $11 \%$ relative to Q1 2019. ${ }^{5}$

Similar impacts were observed in other regions. Pandemic restrictions adversely affected tax revenues in most countries in South Asia. In Malaysia, tax revenue declined by $38.1 \%$ in the second quarter (April-June) of fiscal year 2020 compared to the same period in the previous financial year. Direct tax collection decreased $40.8 \%$, mainly attributable to a decrease in the collection of corporate income tax and petroleum tax. Indirect tax collection dropped $31.1 \%$ owing to a decline in collections of excise and export duties. Other indirect taxes such as sales and service taxes also recorded lower collections compared to corresponding quarters in 2019. The relatively sharp drop in direct taxes could be the result of more direct tax interventions and a drop in the tax base in the form of business profits and individual incomes (Table 1).

In India, total tax collection declined by $24 \%$ during the period from April to August in 2020 against the same period of the previous year. A disaggregated analysis of tax revenues reveals that the immediate impact of the pandemic on direct taxes was greater than that on indirect taxes. The total direct taxes collected during April-August 2020 fell by $33 \%$ while total indirect taxes fell by $17 \%$ compared to their respective collections during the same period of the previous year (Table 2).

Table 1: Disaggregated Trends in Tax Revenues (Malaysia)

\begin{tabular}{|l|c|c|c|}
\hline \multicolumn{1}{|c|}{ Type of Tax } & $\begin{array}{c}\text { Q2 (Apr-Jun) } \\
\text { FY 2019 (RM billion) }\end{array}$ & $\begin{array}{c}\text { Q2 (Apr-Jun) } \\
\text { FY 2020 (RM billion) }\end{array}$ & \% Change \\
\hline Direct Tax & 31.4 & 18.6 & $-40.8 \%$ \\
\hline Indirect Tax & 11.9 & 8.2 & $-31.1 \%$ \\
\hline Total Tax & 43.3 & 26.8 & $-38.1 \%$ \\
\hline
\end{tabular}

$\mathrm{Q}=$ quarter, $\mathrm{RM}=$ ringgit.

Note: Fiscal Year (FY) for Malaysia is from 1 January to 31 December.

Source: Government of Malaysia, Ministry of Finance.

\footnotetext{
3 Reuters. 2020. Japan's April Tax Revenues See Biggest Monthly Drop in Over a Decade. 1 June. https://www.reuters.com/article/ health-coronavirus-japan-tax/japans-april-tax-revenues-see-biggest-monthly-drop-in-over-a-decade-idINL4N2DE25X.

4 The Economic Times. 2020. China Fiscal Revenue Plunges 26.1\% as Virus Ravages Economy. 20 April. https://economictimes. indiatimes.com/news/international/business/chinas-fiscal-revenue-plunges-26-1-as-virus-ravages-economy/ articleshow/75244701.cms.

5 OECD. 2020. Tax Policy and Administration Responses to COVID-19. In Revenue Statistics in Asian and Pacific Economies 2020. OECD Publishing: Paris. https://doi.org/10.1787/a06bffa0-en.
}

A disaggregated analysis of tax revenues reveals that the immediate impact of the pandemic on direct taxes was greater than that on indirect taxes. 
These numbers

illustrate tax

revenue contraction

in the initial months

of the calendar year

soon after countries

introduced

lockdown

measures.

Table 2 : Disaggregated Trends in Tax Revenues (India)

\begin{tabular}{|l|c|c|c|}
\hline \multicolumn{1}{|c|}{ Type of Tax } & $\begin{array}{c}\text { April-Aug FY 2019 } \\
\text { (₹ billion) }\end{array}$ & $\begin{array}{c}\text { April-Aug FY 2020 } \\
\text { (₹ billion) }\end{array}$ & $\begin{array}{c}\% \\
\text { Change }\end{array}$ \\
\hline Net Direct Tax & $2,823.27$ & $1,882.99$ & $-33 \%$ \\
\hline Net Indirect Tax & $3,784.47$ & $3,159.01$ & $-17 \%$ \\
\hline Net total tax (Direct + Indirect) & $6,607.74$ & $5,042.00$ & $-24 \%$ \\
\hline
\end{tabular}

$₹=$ Indian rupee.

Note: Fiscal Year (FY) for India is 1 April to 31 March.

Source: Government of India, Ministry of Finance (data from the Controller General of Accounts).

To assess the level of recovery in tax collection, we examined the monthly tax revenue data for selected countries in the Asia and Pacific region. The data from Nepal reveals that monthly tax revenues fell continuously from January 2020 to May 2020 (Figure 1). Monthly tax collection in January 2020 was NRs10,7761 million, which fell $88 \%$ in May 2020 when only NRs13,459 million was collected. However, post-May 2020, Nepal witnessed a sharp recovery in the last 2 months of the fiscal year. In the last month of its fiscal year (July 2020), the monthly tax collection rose $720 \%$ from collections in May of the same year. The recovery partly reflects seasonality in the tax collection data.
Before the pandemic, Thailand's economy depended heavily on tourism and saw dramatic impacts on public revenue in January and February 2020. Tax collection took the hardest hit in April 2020 when monthly collections declined by $31.3 \%$ compared to April 2019. However, signs of recovery were observed beginning in July 2020 and tax collections saw growth of $29.4 \%$ in August FY 2020 compared to the same month in FY 2019 (Figure 2).

In Pakistan, regional governments started imposing lockdowns in the last week of March 2020. The effects on tax collections by the Government of Pakistan saw a steep decline in April and May (Figure 3). Direct tax collection for Q4 (April-June) in FY 2019-2020 stood at PRs380.8 billion and

\section{Figure 1: Trend in Monthly Tax Revenue Collection (Nepal)}

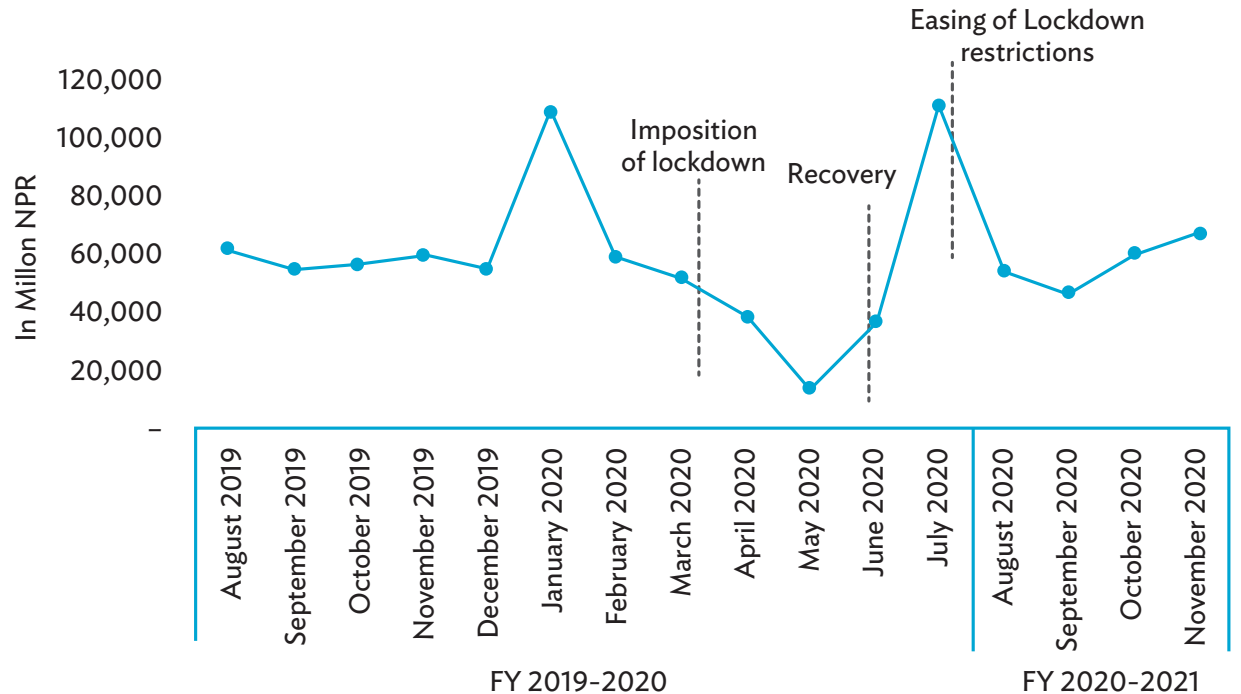

NRs = Nepalese rupees.

Notes: Nepal's fiscal year (FY) is from 16 July to 15 July. The figures represent tax collected from the 16 th of the previous month to the 15th of that month.

Source: Ministry of Finance, Government of Nepal. 


\section{Figure 2: Total Tax Collection (Thailand)}

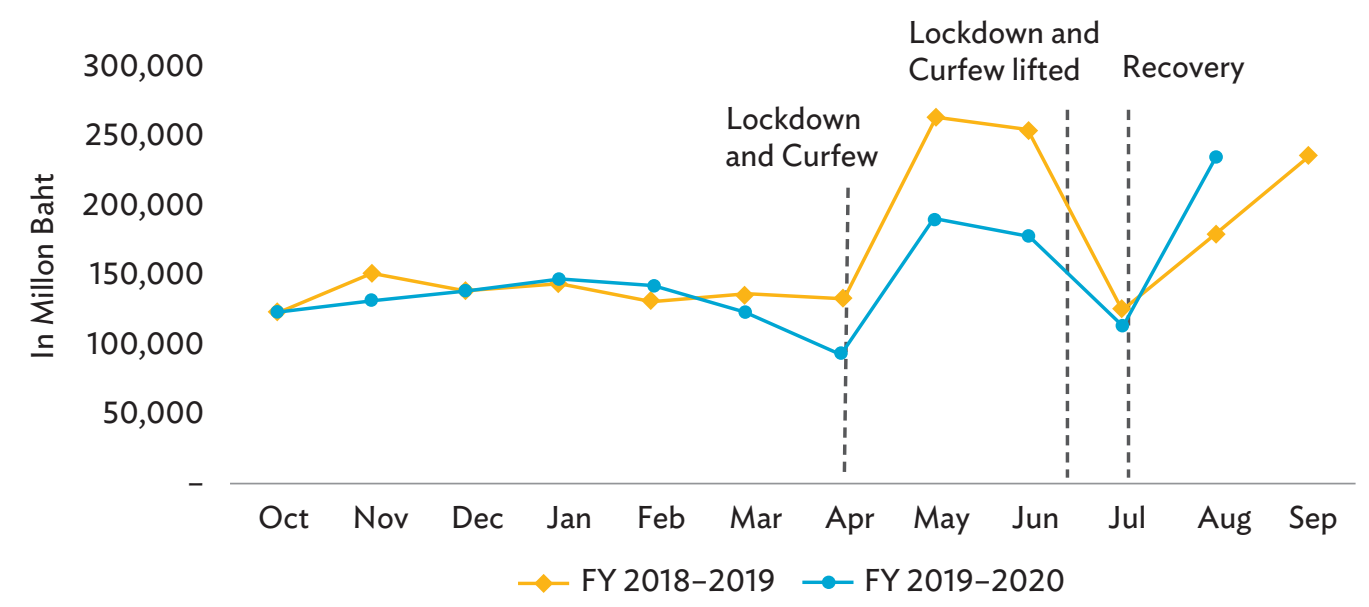

Notes: Thailand's fiscal year (FY) is from 1 October to 31 September.

Source: Ministry of Finance, Government of Thailand.

\section{Figure 3: Trends in Net Tax Collection (Pakistan)}

PRs $=$ Pakistan rupees

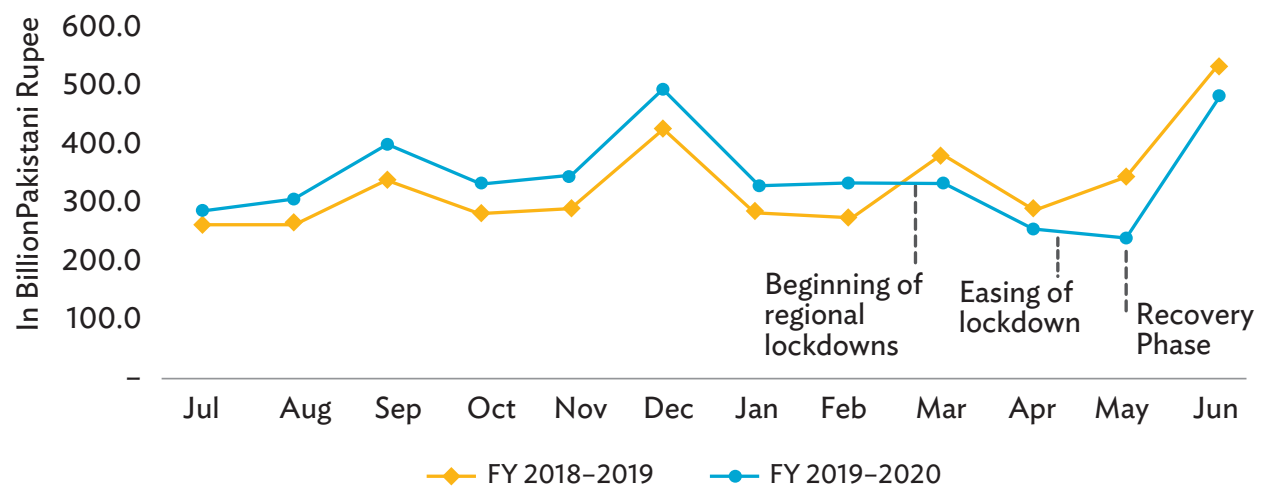

Note: Pakistan's fiscal year (FY) is from 1 July to 30 June.

Source: Government of Pakistan, Federal Board of Revenue.

fell by $15.8 \%$ from PRs 452.3 billion during the same period in FY 2018-2019. Similarly, sales tax collections dropped by 17.3\% in Q4 FY 2019-2020 compared to Q4 FY 2018-2019. A steep recovery was observed in June, the last month of FY 2019-2020. While tax revenue collections in May 2020 stood at PRs229.3 billion, they increased by $102.4 \%$ to PRs464.0 billion in June 2020. This can be partly attributed to the practice of 'bunching' tax collections at the fiscal year end.
These numbers illustrate tax revenue contraction in the initial months of the calendar year soon after countries introduced lockdown measures. In most countries, contractions in tax revenue continued into May 2020. For several countries, this downturn was larger for direct tax collections and to a smaller extent for indirect taxes. Significant reductions in employment and wages, coupled with various direct tax relief measures provided by tax administrations, led to the low collection of direct taxes. 
It can be observed that when countries lifted restrictions and confinement measures in the second quarter of the calendar year (April-June), there was a significant recovery in tax collections, possibly aided by the seasonality in tax collections in some cases. ${ }^{6}$

\section{Asymmetric Impact of COVID-19 on Business Sectors}

The pandemic and subsequent lockdown measures led to a slowdown in economic activities across sectors which resulted in falling tax yields. Though these measures affected most industries, the quantum of impact varied by sector. Given the importance of different sectors in a country's GDP, the overall economic impact has been asymmetric. For example, in Maldives and Fiji, and to a lesser extent Thailand and Sri Lanka, where the economy depended heavily on tourism, there was a greater economic shock compared to other countries. ${ }^{\text {? }}$ It is now clear that certain industries and lines of business such as tourism, passenger transport, hotels and restaurants, and entertainment were hit hard, while the impact has been less or even positive for the financial sector, online retailing, and the infotech sector. An understanding of the pandemic impact on various businesses offers a pointer to the revenue impact. The greater the weight in the GDP of heavily affected sectors, the greater the impact on aggregate GDP and aggregate revenue collections. When sectoral contributions to revenue collections are available from the concerned government, the disaggregated impact on sectors provides an indication of the revenue impact. Also, monitoring disaggregated information helps identify and design targeted interventions and helps ensure a speedy recovery, design an appropriate exit strategy from relief and recovery policy packages, and build resilience for managing future shocks of this nature.

As an example of the differential impact of the pandemic and subsequent lockdowns on various economic activities, data on readily available high-frequency indicators for India are provided in Table 3. These figures were also used to make quick estimates of GDP. While these data have their limitations (i.e., they do not cover several areas of economic activity such as agriculture or consumer spending), they do indicate the extent of the negative impact on the economy and the varying

\section{Table 3: Percentage Change in Indicators (India)}

\begin{tabular}{|l|c|c|}
\hline \multicolumn{1}{|c|}{ Indicator } & $\begin{array}{c}\text { Q1 (2019-2020) } \\
\text { April-June }\end{array}$ & $\begin{array}{c}\text { Q1 (2020-2021) } \\
\text { April-June }\end{array}$ \\
\hline Railway passenger kilometers & -2.2 & -99.5 \\
\hline Passengers handled at airports & -0.6 & -94.1 \\
\hline Sale of commercial vehicles & -9.5 & -84.8 \\
\hline Cargo handled at airports & -6.5 & -57.2 \\
\hline Consumption of steel & 5 & -56.8 \\
\hline Metallic minerals (index of industrial production) & 17.9 & -43.3 \\
\hline Manufacturing (index of industrial production) & 2.4 & -40.7 \\
\hline Production of cement & 1 & -38.3 \\
\hline Mining (index of industrial production) & 3 & -22.4 \\
\hline Cargo handled at major seaports & 1.7 & -19.8 \\
\hline Electricity (index of industrial production) & 7.3 & -15.8 \\
\hline Production of coal & 2.6 & -15.0 \\
\hline Life insurance corporate premiums (non-linked) & 35.6 & -14.7 \\
\hline Production of crude oil & -6.8 & -6.5 \\
\hline Total telephone subscribers & 1.5 & -2.0 \\
\hline Aggregate bank credits & 11.9 & 5.6 \\
\hline Aggregate bank deposits & 10.4 & 9.6 \\
\hline
\end{tabular}

Source: Government of India, Central Statistical Office.

6 In general, monthly tax collections show a jump during the last quarter of the financial year.

Tourism as a share of GDP_Maldives: 28\%, Fiji: 24\%, Sri Lanka and Thailand: 13\%. 
impact on the sectors covered. It can be seen from the data that the banking sector has been affected the least. A small negative impact is seen in the Telecom sector, while passenger transport was rendered almost idle. Similar data from other countries can show the asymmetric impact on sectors of their economies.

To appreciate the impact of the changes in a sector on the overall economy, it is important to look at several economic parameters such as the export orientation of the sector, foreign direct investment equity inflows into the sector, contribution to employment, cash flow constraints, supply chain disruptions, and consumer sentiment. A detailed analysis of these parameters helps identify short- and long-term targeted interventions for a faster recovery of the affected businesses.

\section{Tax Policy Responses to COVID-19: A Review of Relief Measures in Selected Countries in the Asia and Pacific Region}

Governments across the world introduced relief and recovery measures to address the adverse economic impacts of COVID-19 in their respective jurisdictions. These packages include fiscal, monetary, and other measures. Although this brief focuses on the taxation aspect of these measures, it is important to understand their role in the context of the overall design of fiscal stimuli provided by the countries. The following features are considered:

- Overall share of fiscal support as a percentage of GDP

- Comparative analysis of the magnitude of spending measures

- An overview of tax relief measures provided in terms of changes in tax administration and tax structure

- Relative role of government expenditure vis-àvis taxation measures

- Commonly used taxation measures adopted by countries in the Asia and Pacific region

- Extent to which countries in the region have relied on targeted approaches vis-à-vis "blanket" approach while providing tax stimuli.
Design of Stimuli

The Appendix provides information on the broad contours of fiscal packages offered by selected countries in the Asia and Pacific region. It can be observed that Pacific and East Asian economies have been more aggressive in providing fiscal packages compared to their counterparts in other regions. ${ }^{8}$ For example, Japan introduced two economic packages under fiscal measures amounting to $21 \%$ of 2019 GDP to support businesses and households. Similarly, Australia announced fiscal measures amounting to $14 \%$ of GDP and New Zealand announced measures equivalent to $19.5 \%$ of GDP. In comparison, the South Asian region has been more conservative. ${ }^{9}$ Although there was considerable variation in the magnitude of fiscal packages on the spending side, tax policy interventions remained the common element in most adopted fiscal packages for economic recovery.

While the relative importance of spending and tax measures in different countries is a matter of interpretation, the budgetary costs on the expenditure side appear to outweigh those of the tax measures in general. This is largely because (a) tax measures are mostly comprised of deferrals of tax obligations, possibly within the financial year, and (b) expenditures are upfront and easily estimated and accounted for, while the tax costs can only be estimated. In the following discussion, we examine elements of tax relief measures, their intended objectives, the design of tax stimuli adopted by countries in the Asia and Pacific region including short-term and long-term tax measures, and approaches taken to implementation.

\section{Elements of tax relief measures and objectives} Governments worldwide were quick to put in place tax measures following the outbreak of the pandemic and the lockdowns to curb repercussions on businesses and households. In several cases, these initial packages were followed by subsequent packages as the economic fallout of the pandemic was better understood and the severity of the recessionary tendencies increased (Carrasco 2020). The objective of these tax relief measures is to provide room to maneuver in terms of cash flow to businesses and households and, in the longer term, encourage investment. Available information suggests that tax measures have been effective in

8 The information provided mostly relates to national government level only. As such, comparisons may be impaired by large differences across nations in the level of financial participation of subnational governments in relief and recovery efforts.

9 One possible reason may be that many of these countries lack adequate fiscal space to accommodate a large stimulus package. 
Tax administration

measures are

implemented

by tax agencies

to support the

economy through

implementation

of both financial

and nonfinancial

measures. helping businesses retain workers, provide targeted support to the hardest-hit sectors, shield medium and small enterprises from widespread solvency risks, and prevent large-scale job losses. Based on information collated from jurisdictions in the Asia and Pacific region, we have summarized various tax measures provided to businesses and households under two broad categories: tax administration and tax provisions (listed in Table 4).

Tax administration measures are implemented by tax agencies to support the economy through implementation of both financial and nonfinancial measures. The type of measure and the corresponding objectives are listed in Table 5.

Tax provision responses are measures that reduce tax liabilities and are introduced to support businesses and households, boost consumption and investment, support specific sectors such as health care, meet macroeconomic and other challenges posed by the pandemic, and build resilience to future shocks. The key tax policy measures undertaken were:

(i) Measures to support businesses: The objective is to reduce the tax burden, provide liquidity support to tackle the financial fallout from the pandemic, and to encourage long-term investment. Measures included reductions in effective business tax rates, tax waivers for affected business sectors, enhanced business expenditure allowances, increase in thresholds for low-value asset write-offs, and enhanced loss offset provisions.

(ii) Measures to support households: The objective is to enhance consumption spending and boost the demand side. Governments created a range of spending and tax relief measures to provide income support to households for their sustenance. Under tax policy relief, various measures were undertaken including general and selective reductions in tax rates, reduced rates of interest for non-payment of taxes, and personal income tax exemptions.

(iii) Tax policy measures to support the health sector: The pandemic exacerbated vulnerabilities in the health care sector of many countries. To cushion the immediate impacts on the health sector, governments adopted various tax relief measures such as

Table 4: Two Types of Tax Concessions

\begin{tabular}{|l|l|}
\hline \multicolumn{1}{|c|}{ Tax Administration } & \multicolumn{1}{c|}{ Tax Provisions } \\
\hline Minimizing tax compliance burdens & Reduced social security contributions \\
\hline Curtailment of tax audits & $\begin{array}{l}\text { Reductions in business tax rates other than social } \\
\text { security contributions }\end{array}$ \\
\hline $\begin{array}{l}\text { Changes in the calculation of advance tax } \\
\text { payments to reflect current rather than } \\
\text { last year's tax }\end{array}$ & $\begin{array}{l}\text { Tax waivers (in general or targeted to specific } \\
\text { sectors or firms) }\end{array}$ \\
\hline Speedy tax refunds & $\begin{array}{l}\text { Enhanced tax loss provisions (carry-forward or } \\
\text { carry-backward) }\end{array}$ \\
\hline $\begin{array}{l}\text { Remitting penalties and interest payable, extension } \\
\text { of deadlines }\end{array}$ & $\begin{array}{l}\text { Temporary tax deductions, allowances, and credits } \\
\text { other than tax loss provisions }\end{array}$ \\
\hline Deferral of return filing, payments & \\
\hline
\end{tabular}

Source: Author.

Table 5: Tax Administration Measures and Objectives

\begin{tabular}{|l|l|}
\hline \multicolumn{1}{|c|}{ Tax Administration Measure } & \multicolumn{1}{c|}{ Objective } \\
\hline Extension of deadline & $\begin{array}{l}\text { Additional time is given to file tax returns to reduce the burden of } \\
\text { compliance }\end{array}$ \\
\hline Deferral of payments & Postponement of tax payment to support cash flow \\
\hline Remitting penalties and interest & $\begin{array}{l}\text { Suspension of penalty and interest for late filing to reduce cash flow } \\
\text { burden }\end{array}$ \\
\hline Faster refunds & Easing and speeding the processes for refunds to support cash flow \\
\hline Postponement of audit & Reducing compliance burden of taxpayers during difficult times \\
\hline
\end{tabular}

Source: Author. 
personal income tax reductions for health sector workers, business tax rate cuts or accelerated tax depreciation targeted at production of health equipment, lower goods and service taxes on the health sector such as VAT exemptions and rate reductions for medicines, equipment, and services rendered in the fight against the pandemic.

\section{Design of tax stimuli: What are the most used measures?}

The previous sections focused on the type of tax measures, their elements, and intended objectives. Figure 4 summarizes the design of tax stimuli introduced by 26 countries in the Asia and Pacific region and offers insights into the most used direct and indirect tax measures adopted.

To identify these measures, we scanned the OECD Tax Policy Measures dataset which provides a compilation of measures taken by governments of the countries covered. An examination of these tax stimulus packages shows that extension of time limits on the payment of taxes and tax deferrals have been the most widely adopted measures in the region. In the direct tax category, tax payment deferrals and tax waivers were the most used measures, whereas tax waivers and tax refunds were the most popular indirect tax measures. ${ }^{10}$ Available information suggests that tax concessions were primarily for the benefit of business enterprises and the production side of the economy. This is not surprising as the demand side and individuals and families were mostly taken care of through subsidies, direct transfers and assistance in-kind, supplemented by concessions under personal income taxation.

Regarding country-specific measures, we considered the design of tax stimuli provided by

\section{Extension of time}

limits on the payment of taxes and tax deferrals have been the most widely adopted measures in the region. Available information suggests that tax concessions were primarily for the benefit of business enterprises and the production side of the economy.

\section{Figure 4: Number of Countries Adopting Tax Measures Segregated by Tax Type}

\section{Direct tax measures}

Tax Measures supporting Investment and Tax Waivers Tax Payment Deferral Tax Filing Extension PIT Rate Reductions Flexible Tax Debt Repayment Loss Offset Provisions CIT Rate Reductions Tax Depreciation Provisions

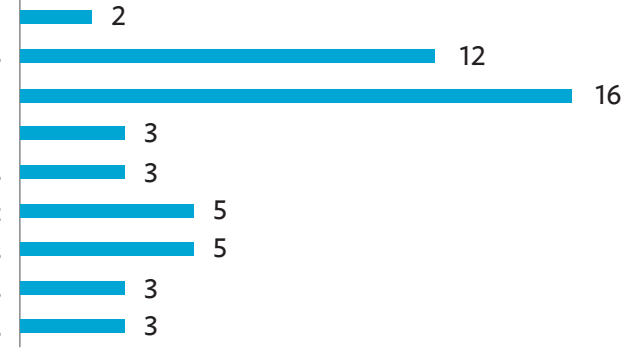

\section{Indirect tax measures}

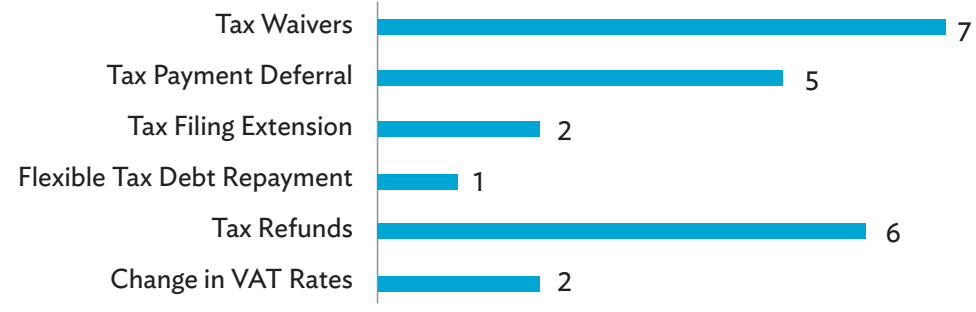

Notes: (i) Flexible Tax Debt Repayments adopted by Georgia could not be classified into direct and indirect measures and were therefore excluded from the analysis. (ii) Tax Filing Extension measures adopted by the PRC could not be classified into direct and indirect measures and were excluded from the analysis.

Source: OECD Tax Policy database.

\footnotetext{
10 Readily available compilations of such measures often do not provide details of the duration of the deferral or waiver. Durations have been revised in several countries, sometimes more than once.
} 
some of the largest economies in the Asia and Pacific region covering the PRC, India, Japan, and Indonesia. In the PRC, direct tax measures included exemptions for personal income tax on bonuses and subsidies paid to health care staff, while indirect measures included tax waivers, enhanced loss offset provisions, enhanced tax refunds, change in tax rates, flexible tax debt repayments, and tax payment deferrals. The Government of India adopted a common approach for extending statutory deadlines for payments of both direct and indirect taxes. Tax administration and tax structure measures introduced by India included flexibility in tax debt repayments and reduced interest rates for non-payment of income tax.

The tax policy responses in Japan included the introduction of legislation for deferral of direct tax payments for people and businesses negatively affected by the pandemic." Similarly, Indonesia introduced income tax waivers for workers in the manufacturing sector with annual incomes of Rp200 million or less along with rate reductions for corporate income tax. ${ }^{12}$ Other tax measures related to indirect taxes included tax payment deferrals and enhanced tax refunds.

\section{Long-term tax reform}

Along with short-term measures introduced as immediate responses to the pandemic, governments also introduced long-term tax reform measures such as enhanced loss offset provisions and stamp duty exemptions along with reductions in corporate taxes, VAT rates, and withholding taxes to support investment and consumption. ${ }^{13}$ These measures aimed to support a sustained economic recovery. Such provisions were common and countries adopting these measures include Cambodia, Fiji, Indonesia, Malaysia and the PRC. For example, Cambodia reduced its withholding tax rate on the interest payments from financial institutions obtaining financing, whether domestically or offshore. The measure was aimed at helping businesses refinance. The government also waived transfer taxes for purchases below $\$ 70,000$ from licensed property developers, effective for one year from February 2020 to January 2021. Similarly, to support investments, the Government of Malaysia announced a 10-year zero tax rate on specified new investments from foreign manufacturers. ${ }^{14}$

Enhanced loss offset provisions constitute another set of long-term tax reform measures introduced in countries in the Asia and Pacific region. For example, in the PRC, some businesses have been given provisions to increase loss carry forward periods from 5 to 8 years for losses incurred in 2020 by some taxpayers that were badly affected by the pandemic. These include transport and catering companies and hotels, lodges, and tourism services. In Uzbekistan, tour operators, travel agents, and accommodation facilities have been allowed to carry forward their losses incurred in 2020 and 2021 without limitations.

\section{Blanket Approaches versus Targeted Approaches}

Governments across the Asia and Pacific region adopted a holistic range of short- and long-term taxation measures. We looked at whether these measures were targeted, provided more of a 'blanket' approach (i.e., no specific targeting), or a combination of both approaches. Targeted measures are aimed at providing tax support to specific households and business groups judged to have been hit the hardest by the pandemic and its economic fallout. In contrast, a blanket approach aims to provide support to all taxpayers irrespective of the socioeconomic impact of the pandemic. A blanket approach may be easier to implement and administer. However, at the same cost, it may not be as effective as a targeted approach. Conversely, targeting may prove extremely effective for most affected businesses and households, but it may significantly increase the administrative cost. Thus, the pros and cons of both approaches need to be carefully considered by policymakers when designing a tax stimulus.

Our preceding discussion of the contours of the tax relief measures provided by selected countries in the Asia and Pacific region shows that certain jurisdictions, such as the PRC and Indonesia, have used targeted measures for the hardest-hit sectors along with more broad-based measures. Special

11 Those corporate and individual taxpayers (national government) whose tax payments were due between 1 February 2020 and 31 January 2021 were given a 1-year deferral provided they suffered a fall in revenue of at least $20 \%$ during the financial year (as per April 2020 legislation).

12 While this exemplifies the introduction of some element of progressivity into the tax stimuli, there is not enough cross-country information available to make any general observations.

13 OECD Tax Policy Database. https://www.oecd.org/ctp/tax-policy/tax-database/ (accessed 23 October 2020).

14 Some of these measures could be part of normal tax reform, excluding the extension of time horizons on loss offsets, which relate specifically to losses during 2020-2021. 
tax benefits were provided to the health sector with the twin objectives of meeting the challenges posed by the pandemic in the short run and building a robust health infrastructure for handling future shocks. Some targeted measures (both direct and indirect) include income tax exemptions for certain workers, personal income tax and corporate income tax waivers for the health care sector, exemptions of import taxes for certain businesses, provisions for increased loss-carry forward for affected businesses in sectors such as transport, catering, accommodation, and tourism, and income tax refunds to businesses engaged in the production of health supplies. Special tax benefits designed for target groups such as small-scale producers and taxpayers can also be seen. Targeting based on location has been employed in the PRC. ${ }^{15}$ For example, specific incentives were provided for businesses in Hubei Province, one of the most severely affected regions in the PRC. Corporate income tax incentives included more flexibility in tax filing extensions and VAT exemptions for small-scale taxpayers in the province were also allowed.

Indonesia introduced strong measures for companies and workers engaged in the manufacturing sector. For example, the government exempted manufacturing workers from personal income tax. It also exempted personal income tax on the additional income for health workers providing pandemic services. The government exempted import taxes for manufacturing companies in 19 sectors for 6 months. In a measure to boost investment, the government declared a grant of an additional $30 \%$ reduction for domestic businesses on taxable income for costs incurred to produce medical devices or household health supplies to fight the pandemic.

Similar measures were undertaken in the PRC where the government provided targeted personal income tax and corporate income tax measures to specific individuals and businesses. For example, exemptions for bonuses and subsidies paid to health care staff were provided as part of personal income tax measures. For corporate income tax incentives, the government increased loss-carry forwards from 5 to 8 years for losses incurred in 2020 for seriously affected businesses. The PRC also provided VAT exemptions on medical services, catering and accommodation services, hairdressing and laundry services, and public transportation and express delivery services provided to individuals.

\section{Estimating the Impact of Concessions on Tax Collections}

The impact of the pandemic and the consequent restrictive measures adversely affected national income aggregates such as GDP in most countries. This reduced tax collections. Tax stimuli announced to arrest recessionary trends and foster recovery could also have affected tax revenues. While the overall impact was outlined in section 2 , here we indicate the impact of tax concessions only. The first step involves a projection of tax collections based on available data on contraction (or otherwise) in GDP. The difference between these projections and the actual collections provides estimates of the revenue costs of the tax concessions taken together. The data and computations for four countries in the Asia and Pacific region are provided. While the computations are simple enough, it should be noted that for projecting tax revenues given GDP, the most common method is based on estimated buoyancy. ${ }^{16}$ In the present estimates, we were unable to use this method as buoyancy-based estimates are appropriate for wholeyear estimates but not for within-year or part-year projections because of the seasonality present in most monthly and quarterly tax revenue data series. To overcome this limitation, we used a simplified method as described in the notes in Tables 6, 7, 8, and 9.

The estimates for India show that actual tax collections could have been higher by about $15 \%$ in the absence of tax concessions during the first quarter (April to June) of FY 2020-2021. In Malaysia, the number was about 10\% in the first quarter (January to March), and 33\% in the second quarter. In Thailand, there was no loss in the first quarter (January to March), but the second quarter tax loss amounted to over $20 \%$ of actual collections. In Australia, there was no loss in the first quarter of the calendar year 2020 but in the second, tax collections could have been higher by about $3 \%$ without the tax concessions. This sample of four countries shows how widely divergent the estimated tax losses have been because of tax concessions, partly because the extent of the concessions varied. Tempting as it is to compare the costs of tax concessions provided by different countries, more data than currently available would be required, particularly in view of the fact that different countries introduced tax measures at different times and with subsequent additions and alterations to the packages initially announced. Modification is an ongoing process in most countries.

\footnotetext{
15 OECD Tax Policy Database https://www.oecd.org/ctp/tax-policy/tax-database/ (accessed 23 October 2020)

16 To be related to tax revenue data, GDP data should be in current prices.
} 
Table 6: Estimated Tax Loss on Account of Tax Concessions Only (India) (₹ 10 million)

\begin{tabular}{|l|c|c|c|c|c|c|c|}
\hline & \multicolumn{3}{|c|}{ FY 2019-2020 } & \multicolumn{3}{c|}{ FY 2020-2021 } & Estimated \\
\hline & Tax & GDP & $\begin{array}{c}\text { Tax/GDP } \\
(\%)\end{array}$ & Tax & GDP & $\begin{array}{c}\text { Tax } \\
\text { Estimate }^{\mathrm{a}}\end{array}$ & $\begin{array}{c}\text { Tax Loss } \\
(\%)^{\mathrm{b}}\end{array}$ \\
\hline Q1 & 400,421 & $4,918,228$ & 8.14 & 269,686 & $3,808,193$ & 310,047 & 14.97 \\
\hline Q2 & 519,049 & $4,465,838$ & 11.62 & & & & \\
\hline Q3 & 463,565 & $4,675,351$ & 9.92 & & & & \\
\hline Q4 & 626,847 & $4,712,757$ & 13.30 & & & & \\
\hline Total & $2,009,882$ & $18,772,174$ & 10.71 & & & & \\
\hline
\end{tabular}

$₹=$ Indian rupee, $\mathrm{FY}=$ fiscal year, $\mathrm{GDP}=$ gross domestic product, $\mathrm{Q}=$ quarter.

a Based on the tax-GDP ratio of the previous year.

${ }^{b}$ Loss on account of tax concessions as \% of actual tax collection.

Sources: Government of India, Ministry of Finance (Controller General of Accounts) and Ministry of Statistics and Programme Implementation.

Table 7: Estimated Tax Loss on Account of Tax Concessions Only (Malaysia) (RM billion)

\begin{tabular}{|l|c|c|c|c|c|c|c|}
\hline \multicolumn{3}{|c|}{ FY 2019-2020 } & \multicolumn{4}{c|}{ FY 2020-2021 } \\
\hline & Tax & GDP & $\begin{array}{c}\text { Tax/GDP } \\
(\%)\end{array}$ & Tax & GDP & $\begin{array}{c}\text { Tax } \\
\text { Estimate }^{\mathrm{a}}\end{array}$ & $\begin{array}{c}\text { Estimated } \\
\text { Tax Loss } \\
(\%)^{\mathrm{b}}\end{array}$ \\
\hline Q1 & 41.8 & 361.97 & 11.55 & 38.4 & 367.21 & 42 & 10.42 \\
\hline Q2 & 43.4 & 371.02 & 11.70 & 26.8 & 301.89 & 35 & 33.58 \\
\hline Q3 & 46.1 & 381.53 & 12.08 & & & & \\
\hline Q4 & 49.3 & 396.23 & 12.44 & & & & \\
\hline Total & 180.6 & $1,510.76$ & 11.95 & 65.2 & 669.10 & & \\
\hline
\end{tabular}

$\mathrm{RM}=$ ringgit, $\mathrm{FY}=$ fiscal year, $\mathrm{GDP}=$ gross domestic product, $\mathrm{Q}=$ quarter.

a Based on the tax-GDP ratio of the previous year.

b Loss on account of tax concessions as \% of actual tax collection.

Sources: Government of Malaysia, Ministry of Finance and Department of Statistics.

Table 8: Estimated Tax Loss on Account of Tax Concessions Only (Thailand) (B Million)

\begin{tabular}{|l|r|c|c|c|c|c|c|}
\hline & \multicolumn{3}{|c|}{ FY 2019-2020 } & \multicolumn{3}{c|}{ FY 2020-2021 } \\
\hline & Tax & GDP & $\begin{array}{c}\text { Tax/GDP } \\
(\%)\end{array}$ & Tax & GDP & $\begin{array}{c}\text { Tax } \\
\text { Estimate }^{\mathrm{a}}\end{array}$ & $\begin{array}{c}\text { Estimated } \\
\text { Tax Loss } \\
(\%)^{\mathrm{b}}\end{array}$ \\
\hline Q1 & 411,123 & $4,217,970$ & 9.75 & 412,800 & $4,161,945$ & 405,662 & -1.73 \\
\hline Q2 & 648,180 & $4,147,950$ & 15.63 & 459,242 & $3,546,985$ & 554,270 & 20.69 \\
\hline Q3 & 537,561 & $4,175,125$ & 12.88 & & & & \\
\hline Q4 & 393,274 & $4,334,846$ & 9.07 & & & & \\
\hline Total & $1,990,137$ & $1,6875,891$ & 11.79 & & & & \\
\hline
\end{tabular}

$\mathrm{B}=$ baht, $\mathrm{FY}=$ fiscal year, GDP = gross domestic product, $\mathrm{Q}=$ quarter.

a Based on the tax-GDP ratio of the previous year.

b Loss on account of tax concessions as \% of actual tax collection.

Source: Government of Thailand, Office of the National Economic and Social Development Council. 
Table 9: Estimated Tax Loss on Account of Tax Concessions Only (Australia) (A \$ million)

\begin{tabular}{|l|c|c|c|c|c|c|c|}
\hline & \multicolumn{3}{|c|}{2019} & \multicolumn{3}{c|}{2020} \\
\hline & Tax & GDP & $\begin{array}{c}\text { Tax/GDP } \\
(\%)\end{array}$ & Tax & GDP & $\begin{array}{c}\text { Tax } \\
\text { Estimate }\end{array}$ & $\begin{array}{c}\text { Estimated } \\
\text { Tax Loss } \\
(\%)^{b}\end{array}$ \\
\hline Q1 & 138,411 & 471,362 & 29.36 & 144,327 & 487,118 & 143,038 & -0.89 \\
\hline Q2 & 153,658 & 499,667 & 30.75 & 140,777 & 470,445 & 144,672 & 2.77 \\
\hline Q3 & 132,288 & 503,307 & 26.28 & & & & \\
\hline Q4 & 147,069 & 520,729 & 28.24 & & & & \\
\hline Total & 571,426 & $1,995,065$ & 28.64 & 285,104 & 957,563 & & \\
\hline
\end{tabular}

$\mathrm{A} \$=$ Australian dollar, $\mathrm{FY}=$ fiscal year, $\mathrm{GDP}=$ gross domestic product, $\mathrm{Q}=$ quarter.

a Based on the tax-GDP ratio of the previous year.

b Loss on account of tax concessions as \% of actual tax collection.

Source: Australian Bureau of Statistics. Policy Considerations for an Exit Strategy to Withdraw Tax Stimulus Measures

\section{Policy Considerations for an Exit Strategy to Withdraw Tax Stimulus Measures}

\section{Cost of Tax Stimulus versus Tax Cost of the} Economic Downturn

Tax stimulus packages to boost economic activities are introduced during recessionary episodes as a counter-cyclical response when policymakers at least implicitly assess the economic cost of the package to be less than the cost imposed by the downturn in the economy (i.e., of no economic policy response). Tax stimulus costs (CTI in
Figure 5) are of two types: (a) the direct costs in foregone revenue from the tax relief measure and (b) the indirect costs imposed by foregone public expenditures, or alternatively by additional borrowing. The costs of the downturn (CR in Figure 5), relate to the loss of private income and lower tax revenues resulting from a lower tax base from a lower GDP. Conceptually, the greater the latter type of costs, the smaller the former. This is because when tax bases are lower, the notional cost of tax incentives will fall since taxpayers can take less advantage of tax incentives. The more effective the tax stimulus, the greater the tax loss.

\section{Figure 5: Costs of Tax Incentives and Recession}

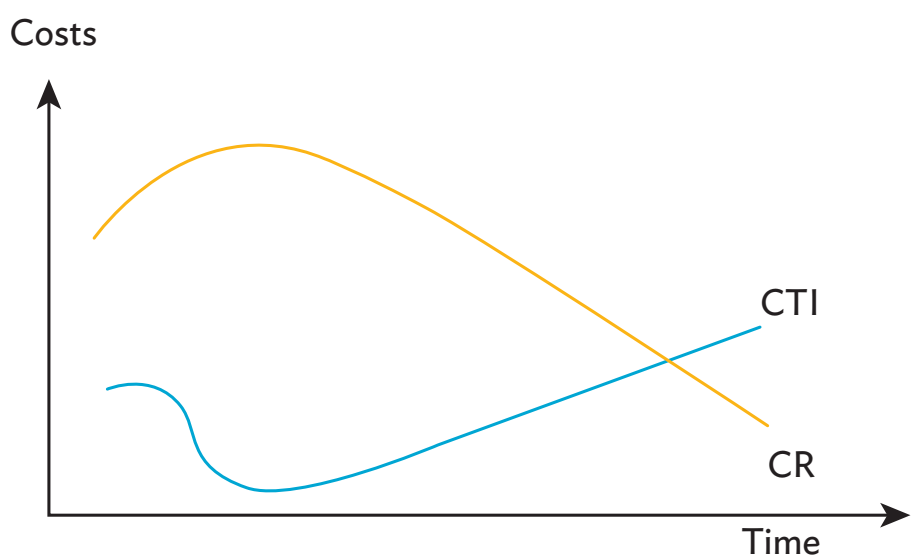

$\mathrm{CTI}=$ Cost of Tax Incentives, CR = Cost of Recession.

Source: Author. 
Conceptually, special

tax stimuli will not be

economic beyond a

point where the tax

stimuli costs become

higher than the cost

of the recession.
It is possible to make a rough estimate of the revenue loss because of the economic downturn and the tax stimulus package together; for example, a trend projection of tax revenues based on pre-downturn data minus the actual revenue collections would provide a reasonable approximation. However, it is much less straightforward to disentangle the two types of losses attributable to tax stimuli and economic downturn. This is because both may happen simultaneously. It may be possible for a government to systematically review the data for tax expenditures from the concerned departments and derive the tax loss attributable to the downturn as a residual from the estimate of total tax loss. ${ }^{17}$ We looked closely at the issue of the impact of the pandemic-induced recession on tax collections in Section 3. Estimates of the direct costs of tax concessions in terms of tax revenue foregone for a few selected countries were also provided in Section 4.

Issues and Challenges in Exit Strategies: How and When to Ease Economic Stimuli?

This discussion of the relative costs of tax stimuli and the economic slowdown brings into focus that at some point, the former may outweigh the latter. As economic activity recovers, the costs of the recession will decline and production and consumption activities will gradually raise the cost of tax incentives (Figure 5). Conceptually, special tax stimuli will not be economic beyond a point where the tax stimuli costs become higher than the cost of the recession. Practical considerations like ensuring the durability and sustainability of the recovery process may require the continuation of stimuli for some time, but budgetary considerations must prevail at some point and the government must exit from the special tax concessions.

Three issues need to be decided when exiting from tax stimuli. These are the what, when, and how of the exit. First, a decision must be taken as to whether an exit from various tax concessions can be put into effect simultaneously or if a withdrawal can be broken up into components of a package and implemented separately. Second, the government must carefully choose the timing of any withdrawal. The guiding principle has been laid out in the preceding paragraph. In practice, estimating and comparing the two types of costs may not be tractable or feasible for government decision-makers in real-time and a simpler approach is needed. Essentially, a government needs a clear idea of the turnaround from the recession since they would likely be aware of the budgetary costs of the tax concessions. A commonly used method for locating the reversal in recessionary trends is to track pre-identified, known indicators of economic trajectory. Third, the government has a choice of gradually winding down special concessions, or withdrawing them in full and going back to the normal tax structure . $^{18}$

\section{Disaggregating the Exit: Staggered or All-at-Once?}

In principle, any government having introduced a fiscal package to revitalize economic activities has the choice of withdrawing those special measures simultaneously or considering each separately. Partly, such a decision depends on the nature of the special incentives. If the incentive is general in nature, the exit is likely to be considered in the same terms. However, even in such cases, the exit can provide for exceptions to be considered. Most packages consist of several incentives that involve different public agencies, provide the impetus for economic revival of different natures, and often target different groups of economic agents. In most cases, the measures that constitute a total fiscal package are not introduced together. More often than not, disaggregating the exit is feasible. The question is, is it also preferable?

There are three lines of argument for a simultaneous withdrawal. The first argues that an economy is an integrated structure because of interlinkages between different economic groups, and thus, ought to be treated as such. Any differential treatment of constituent parts of the economy can provide windfall gains to some, and this can disturb the balance of the economy (the general equilibrium) and negatively impact the efficiency of resource allocation causing welfare losses. The second line of argument is that a concerted exit is preferable for reasons of political economy. Because the bottom line for tax stimulus measures is higher returns and higher disposable income, disaggregating the exit would amount to variations in these benefits. Such variations can trigger a scramble to appropriate the benefits and cause inefficient practices such as lobbying and other rent-seeking activities, which have the

17 Tax expenditures are the sum of tax savings made by taxpayers using the tax incentives.

18 For example, if a special investment allowance of $20 \%$ has been given, it can be first reduced to $10 \%$ for some time before being withdrawn completely. 
potential to defeat the original objectives. ${ }^{19} \mathrm{~A}$ third line of argument emphasizes that decision making is administratively easier if it is not disaggregated and is based on macroeconomic factors only. Any disaggregation would call for a larger number of decisions based on much more detailed information and analysis of such information. The necessary skills may not be available in all contexts.

The nature and manner of the introduction of the tax stimuli can determine the manner of their withdrawal. If the measures are in the nature of tax deferrals and deferrals of compliance (e.g., extending the deadline for submission of tax returns), then typically, such measures stipulate a period for the deferral and the exit date is known. Certain other measures such as lengthening the period for carry-forward of losses is inherently long-term and should not be withdrawn in the short run to have the desired impact. It is measures like reduction in tax rates or special treatment of specific groups that require careful consideration before exiting. Also, if different tax measures have been introduced at different times, it can signify a differential impact of the pandemic on the concerned tax bases. In such cases, the differential can persist into the recovery when the economic impact of the pandemic recedes. A similar outcome is likely if general confinement strategies like lockdowns are relaxed in stages. ${ }^{20}$ Not all economic activities will come out of recession at the same speed. Recovery may be faster or slower depending on the nature of the industry and its market situation. To be fair to taxpayers and to prevent tax-induced disruptions in the structure of the economy, such a scenario would call for an exit strategy that is nuanced and fine-tuned to the required recovery period of the type of business or activity.

It thus appears that a disaggregated exit strategy for a tax stimulus package is inevitable for most countries. Blanket withdrawal appears to be a viable strategy only in countries that have a largely unidimensional package (i.e., depending on a single major tax stimulus). However, not all the arguments for an aggregative strategy should be dismissed. On balance, it appears that economies prone to rent-seeking activities and without adequately skilled administrative support for decision-makers may do better to adopt a one-off approach.
Timing: Identification and Use of Triggers

The importance of timing an exit from a tax stimulus has been emphasized by many. This is mainly in the context of avoiding unnecessary tax losses when the battle with the pandemic has strained the sustainability of public finances in several nations, particularly among low-income groups. The discussion to this point has indicated that the timing of an exit from tax stimuli that are not pre-defined would come down to correctly identifying the turning point in the economy, which in turn would require the identification of some easy-to-interpret indicators. The literature is replete with suggested indicators of business cycles, but for actual decision making, such indicators must fulfil two requirements: (a) they must be available with high frequency (at least monthly) and (b) they must be leading, or at least concurrent indicators. Lagging indicators are not much help in the present context. At the same time, the use and costs of tax stimuli need to be monitored regularly to get an idea of when the costs start increasing and to help determine their affordability in terms of budgetary considerations.

Regular availability of high-frequency data on leading and concurrent indicators of business cycles vary across economies. The choice of indicators is constrained by the availability of data. Given this constraint, the chosen indicators should reflect movements in major macroeconomic variables like GDP, employment, consumer spending, business sentiment, and investment. The literature also points to other variables such as stock prices, interest rates, and the general price index. However, some discretion is needed in their use because stock prices are easily swayed by non-substantive or fundamental factors without a strong link to the real economy, interest rates are often administered and not necessarily connected to market conditions, and interpreting movements in the general price index can be difficult since a rise can reflect both a surge in demand or a falling supply.

Commonly available and reliable indicators of a business cycle include electricity consumption, the number of people claiming unemployment benefits, bank credit offtakes, inventory buildup and rundown rates, the Purchasing Managers'

\footnotetext{
19 This is essentially the same argument used to advocate the 'keep it simple' principle of taxation that opposes targeted tax incentives, and 'too much' of rate differentiation.

20 In India, lockdowns were never applicable to agriculture. While lockdowns have been withdrawn for most activities, a large part of the entertainment industry has been under lockdown for the longest period.
}

\section{The literature \\ is replete with suggested indicators of business cycles, but for actual decision making, such indicators must fulfil} two requirements: (a) they must be available with high frequency (at least monthly) and (b) they must be leading, or at least concurrent indicators. 
Index, consumer spending on specific items like automobiles and real estate, occupancy rates of passenger flights and other public transport systems such as railways, and consumption of major petroleum products. For some countries, estimates for the composite leading indicator (CLI) values are available from professional market trackers (for example, OECD prepares CLI for several countries on a regular basis). Typically, these indicators would show a flattening of the curve at the bottom of the business cycle, followed by an upturn. The government concerned may allow a discretionary period to lapse from the upturn before contemplating an exit, primarily to ensure that the upturn is sustainable.

The discussion so far has focused on macroeconomic indicators because of the presumption that an exit strategy would be considered only when there is evidence of a general economic upturn. However, for specific measures, macroeconomic indicators may have to be complemented by sectoral indicators. For example, the withdrawal of special tax benefits for the tourism and hospitality sector would have to be linked to indices reflecting tourist arrivals and occupancy rates of hotels and resorts.

There is the possibility of gradually phasing out a specific tax benefit by withdrawing the benefit in steps. This has the advantage of allowing the beneficiaries to adjust their response in a gradual fashion. The stages of the benefit withdrawal can then be linked to pre-decided values of the specific indices chosen. Such a procedure would depend on the speed with which the concerned government would want to revert to its normal tax provisions and the confidence it has in the chosen index or indices.

\section{Lessons Learned from the Global Financial Crisis}

The global financial crisis starting in 2008 is the only recent example of a widespread recession with the introduction of monetary and fiscal packages to arrest the slide and an eventual exit from those packages. What lessons can be drawn from this example that could inform exit strategies in the current context? Bear in mind that the nature and intensity of the crises are very different, particularly for the Asia and Pacific economies. The 2008 crisis emanated from the financial sector and spread to several industrialized countries through toxic assets. Countries with little exposure to those assets were not significantly affected.
The present pandemic-induced recession is far more widespread in the Asia and Pacific region, especially among countries in the lower-income group and those with significant exposure to industrialized nations through tourism. The tools arrayed against the recessionary trends in the 2008 crisis were comprised primarily of monetary policy instruments. Fiscal instruments, particularly on the expenditure side, were also employed, but to a lesser extent. This was logical, as the root of the problem was in the financial sector and the risk that a greater financial meltdown would lead to a deeper implosion of the real economy. The response in the form of corrective packages was generally quick, and the rebounding economic growth made exit that much easier.

However, even with that easier exit, commentators spoke about the 'compulsions to exit' because of rising debt levels that could make the fiscal stance unsustainable, and the fear of overheating the economy if the stimulus packages persisted for too long. From a different perspective, questions were raised about the distributive impact of the exit strategies employed as well as the timing, alleging 'too early' exits in some industrialized nations. Also, perceptions of quasi-fiscal stimulus operations from monetary authorities and their inability to reverse course in a timely manner created controversy in certain circles.

In the present context, the main lessons are cautionary. That no concerted exit policy is feasible or desirable is well understood, although there was some attempt by the $\mathrm{G} 20$ to coordinate exits in the 2008 episode. It is also understood that each country must fashion its exit strategy with its unique circumstances in view. However, in the absence of safety nets and as job losses and other negative impacts on the poor in several countries in the Asia and Pacific region can be far more debilitating than in the industrialized nations, the distributive issue must figure prominently in any exit policy. Since that would imply a continued reliance on the expenditure side of fiscal packages even after an exit from short-term tax incentives, it highlights the need for a way to do so while simultaneously maintaining fiscal sustainability. An exit from special tax incentives should probably take place first, with monetary policy continuing to provide a counter-cyclical cushion for some time since there is little likelihood of economies overheating this time around. 


\section{Risk Assessment}

The literature on government interventions in the context of fighting recessionary trends in the last 2 decades repeatedly emphasizes three desirable characteristics, timely, targeted, and temporary, popularly christened 'the three Ts' (see for example, Elmendorf and Furman, 2008; and Steel and Harris, 2020). Non-adherence to each of these principles carries anticipated risks that can be illustrated for each case.

- If substantial tax concessions such as instant depreciation or higher investment allowances are provided to encourage investments while a lockdown is in force and demand is low, it is not timely in the sense that investments are not likely to increase until the lockdown is lifted and there is an increase in demand. It is important to understand which type of stimulus is appropriate for which phase of the pandemic and the associated recession.

- A tax stimulus in the form of a general cut in corporate income tax is not targeted. Such a measure disproportionately benefits corporations with larger profits and provides no benefit to those business enterprises who need it the most because their profits have disappeared, and the tax rate does not matter to them. This measure, therefore, carries the risk of failing to meet its objective of aiding survival and revival for a large swathe of business enterprises. Targeting, by definition, is a way to get the maximum value for the cost incurred. Conversely, nontargeted measures run the risk of wasting limited public resources, a consideration particularly relevant for countries with limited fiscal space.

- The risk associated with tax concessions that are not temporary is obvious: these concessions cost resources for the exchequer in foregone revenues, and if they are continued for a long time, the budgetary costs can become too large to maintain even necessary expenditures. Again, this is of greater significance for countries with serious budget constraints.

These considerations apply as much to the present recessionary episode, with uncertainties regarding the future course of the pandemic, as they did for the 2008 episode, with added complications. For example, encouraging certain types of business activities before the complete cessation of COVID-19 infections can undermine social distancing and risk an increase in the incidence of the pandemic.
Besides these general observations, governments need to be aware of several other risks associated with tax concessions. These are:

(i) Risk of tax competition: In a recessionary situation, it is tempting for many countries to reduce effective tax rates to attract foreign investment to aid a recovery, but more than one country can play this game, and the resulting tax competition can inflict costs in the form of lower tax revenues for all.

(ii) Risk of "beggar thy neighbour" policy: In a similar vein, lowering the tax burden on domestic production hoping for a shift in foreign demand from other countries can cause retaliation by other countries, causing all-around loss of revenue.

(iii) Distribution risks: In the context of some of the tax stimuli provided by the Federal Government of the USA, a report by the Joint Committee on Taxation found that " 82 per cent of those who stood to benefit from these provisions earned at least $\$ 1 \mathrm{~m}$ and only 5 per cent make less than $\$ 200,000$ annually." (Financial Times, 2020). Unless tax concessions are carefully designed, the benefits can disproportionately accrue to the rich who do not need them, and their higher propensity to save would dampen the hopedfor boost to aggregate demand.

(iv) Risk of overestimating potential recovery: If the post-crisis potential demand is overestimated by industrialized nations, they may provide too many tax concessions that would cause a glut in their domestic markets, which would eventually affect their imports. This would have repercussions for Asia and Pacific countries with significant economic dependence on exports to these countries at a time when international trade has already been adversely impacted. This argument is similar to that of Zhang and Zhang (2009), who discussed the same risk but with different channels of transmission of the impact (i.e., through overaccommodative monetary policy, inflation, and higher bond rates).

(v) Risk of propping up "zombie" producers: One aspect of market discipline is the exit of inefficient (high cost) firms. Indiscriminate tax subsidies can help such firms survive and continue production. This would result in misallocation of resources and inefficiencies and can even lead to uneconomical import substitution, losing comparative advantages in both domestic and international trade. 


\section{It is difficult to}

provide a generalized

exit strategy for tax

stimuli provided in

the context of the

COVID-19 pandemic, as each nation will

have to tailor an

exit to their unique

circumstances.
It is therefore important to pick winners for tax subsidies to maximize benefits to the nation.

(vi) Risk of vested interests cornering benefits: When providing special tax benefits for specific sectors or groups, it will be important to resist pressure groups and lobbies that try to corner tax subsidies for themselves even when the optimal policy indicates otherwise.

(vii) Risk of getting stuck with tax subsidies: Often, it is difficult for governments to end tax subsidies for political and other reasons, especially if there is no commitment made to phase them out. Announcements of the eventual removal of tax concessions with committed end dates can be helpful in such cases. Such announcements are important when the intention of a commodity tax like a VAT cut is to stimulate consumption to boost aggregate demand.

\section{Recommendations and the Way Forward}

This final section considers strategic issues governing exits and not the desirability or otherwise of tax stimulus measures. It is difficult to provide a generalized exit strategy for tax stimuli provided in the context of the COVID-19 pandemic, as each nation will have to tailor an exit to their unique circumstances. However, broad considerations can be offered.

- Each of the economies in the Asia and Pacific region must continuously monitor its economic health in the macroeconomic space in terms of specific groups and sectors particularly vulnerable or important to their economy. This is necessary to know when to contemplate an exit unless deterioration of the fiscal stance becomes critical even before an economic turnaround. This would entail:

- Identification of the leading/concurrent, highfrequency indicators of economic health to track. The GDP estimate would be the most comprehensive and obvious choice, but early indications can be seen by tracking power consumption, consumption of diesel, and construction activity. For fine-tuning policy responses, sectoral indices, consumption expenditures by the nongovernment sector, and unemployment rates can be tracked.
Economies such as Fiji and Maldives need to track the most important sector for them, which is tourism. There would be some sectors in most economies that would not be strongly affected by a pandemic-induced recession. These sectors need to be identified so they can be excluded while tracking economic indicators to ascertain the end of the recessionary phase; otherwise, they can distort the broader indicators and misinform policy decisions.

- Ascertain the turning point by tracking relevant indicators. There would generally be either a flattening of the curve at the bottom or a $\mathrm{V}$-shaped recovery. Caution is needed to ensure that the turnaround is genuine. It is best to wait a little before rushing to exit from a stimulus.

- A regular check of fiscal balances is needed to ensure that deficits do not cross critical levels. Policymakers need to decide the critical level of deficits, beyond which fiscal stimuli cease to be affordable. Simultaneously, in the specific case of tax stimuli, the budgetary costs of the tax stimuli need to be continuously monitored. It is possible that such costs are relatively small. If so, there would be little urgency to exit from the tax stimuli even after a reversal of recessionary trends is clearly visible. In the opposite case of costs reaching unaffordable levels, an exit may be necessary even before a full turnaround is established.

- Once a turnaround is established, the tax stimuli that permit a discretionary exit need to be identified and a decision taken to exit or otherwise. If an exit is preferred, it must be followed by decisions on the timing and manner of the exit from each of the elements individually and in consultation with the concerned departments. It is important to distinguish between those measures the exit from which would aid immediate recovery of tax revenues from those that do not. The relevant tasks would be:

- Classify the tax stimuli into three categories: (1) those inherently medium- or long-term, such as extensions for loss write-off periods, accelerated depreciation allowances, or higher investment allowances; ${ }^{21}$ (2) those with a pre-defined exit, such as tax payments or tax compliance deferrals; and (3) those not falling in either of the preceding categories.

21 While in general, fiscal policy analysts do not favor long-term stimuli to meet emergencies like the one posed by the pandemic-induced recession, there is a counterview (see Krugman, 2020). 
The stimuli in the first category will remain outside the scope of the exit strategy. Those in the second category require only one type of decision, i.e., whether to extend their period or allow them to end at the pre-decided time. It is the third category where a detailed assessment is needed.

- Each country needs to craft a mid-term revenue strategy that would identify exactly what needs to be done to help the recovery and arrest the slide in revenue generation before returning to normal. These would be tax measures that would balance the continuation of a stimulus with revenue considerations.

- A priori considerations such as differential impacts of the pandemic and the recession on various sectors, and the differing speed of recovery of different sectors argue against a blanket exit policy. However, disaggregating the exit from tax stimuli would then entail an examination of the relevant information in detail and tracking (i) the impact of the recession on, and (ii) the economic recovery of different taxpayer groups, (iii) their use of the stimulus measures, and (iv) the resulting budgetary costs.

- Disaggregation can have varying aspects. Each tax measure comprising the tax stimulus package can be separately considered. Also, disaggregation can be by sector, and a country may differentiate between sectors while choosing the timing of an exit from one or a group of tax concession measures. Our review of tax measures indicates instances of targeted measures. In such cases, the exit requires specific decisions.

- The greater the disaggregation employed in decision making, the greater the need for (i) detailed up-to-date information on the need for and use of tax concessions by groups of taxpayers (e.g., different industries) and (ii) the necessary skills to make use of the information. The extent of disaggregation in the exit strategy can be limited by the lack of either. Also, too much disaggregation may be unnecessary for economies with a few dominant sectors (e.g., tourism or mining). Subject to these caveats, a disaggregated exit strategy would be more appropriate than a blanket exit.
- It is better to err on the side of caution. Unless compelled by budgetary considerations, it is better to continue with stimuli for some time after a turnaround is noticeable.

- While exiting from tax stimuli, if a disaggregated approach is feasible, a general principle is to exit from those stimuli assisting the supply side first and then, after a lag, by those intended to raise aggregate demand. This is because higher demand can motivate producers to raise output even without continued tax concessions, but the converse is not true in the short run when there would be excess capacity.

- Similarly, tax deferrals need to be exited before tax cuts are reversed. This has the advantage of not overloading taxpayers with accumulated tax liabilities on both counts at once. From the revenue collection perspective, an exit from tax cuts will not bring in any revenue if deferrals are still in operation. Sequencing it the other way around would bring in much-needed revenue immediately, albeit at a lower rate of taxes. With subsequent removal of tax cuts, revenue flow would increase.

- It is also possible to think in terms of unconventional fiscal policy to continue stimulating demand while exiting from conventional tax stimuli. Some countries such as Germany and Japan used this approach during the current recessionary episode. This takes the form of (i) cutting consumption taxes now (e.g., VAT), with an announcement of restoring it to the previous level at a fixed future date, or (ii) announcing a rise in consumption taxes at a future date. Both are expected to have the same effect on consumers advancing their purchase plans, but the budgetary implications differ. The first option entails some loss of revenue, while the latter does not entail direct budgetary costs. ${ }^{22}$ However, to be effective, the time lapse between the announcement and the announced change should not be too long, preferably around 6 months, as a long lag does not result in achieving the objective of a quick boost to demand. Such a policy should be combined with policies that boost consumer purchasing power as part of the recovery efforts, as advancing purchase plans in a recessionary recovery phase is feasible only with adequate disposable income in the hands of consumers.
While exiting from tax stimuli, if a disaggregated approach is feasible, a general principle is to exit from those stimuli assisting the supply side first and then, after a lag, by those intended to raise aggregate demand.

\footnotetext{
22 For a more detailed discussion, see D'Acunto, Hoang and Weber (2020).
} 
- While exiting from tax stimuli, it is necessary to ensure that the monetary policy stance is such that it provides a cushion to the economy. This argues for strong coordination between monetary and fiscal authorities. It also points to an exit from tax stimuli preceding an exit from antirecessionary monetary policy.

- Post-exit, methods must be found to correct serious fiscal imbalances without damaging distributive justice (i.e., ways to raise revenues from taxpayers with high net worth and reduce expenditures by targeting their benefits to low-income groups as much as possible). This is because the economic consequences of the pandemic have been far more serious for the poor than for wealthy individuals and households. ${ }^{23}$ There may be some trade-offs between growth and equity as savings and investments are usually largely from high incomes. Therefore, careful consideration is needed to balance these objectives or achieve one objective without damaging another (Mooij et al., 2020).

- In the search for financing, direct taxes appear to be more appropriate in general than indirect taxes, as it may be difficult to prevent the incidence of the latter on the poor. For example, apart from a progressive rate structure, employing a surcharge on personal income tax beyond a certain limit may be appropriate. Also, tax expenditures for personal income tax may be reassessed to eliminate those which do not benefit lower-income groups as much. A simplified presumptive tax regime for small businesses may be considered to ease compliance problems and conserve administrative efforts. All capital income should be taxed as far as possible at the same rate as such incomes generally accrue to better-off individuals.

- Across the board, corporate rate cuts should be reversed as early as feasible. ${ }^{24}$ The US Congressional Budget Office (2008) considers them relatively less effective tax stimuli, although such cuts may be retained for a longer duration for sectors slow to bounce back. A phased withdrawal of measures such as enhanced investment allowances or accelerated depreciation can be considered as an alternative to complete withdrawal in one go. Such cost-based incentives are generally better than profit-based incentives. Redesigning corporate income tax as a rent tax by allowing appropriate deductions such as a minimum rate of return would help without unnecessarily sacrificing revenue.

- In this context, long-term tax reforms that raise tax revenues without further burdening honest, low-income taxpayers can be expedited.

For example, international tax co-operation to weed out tax evasion by ploys such as shifting income around or misusing foreign transactions ought to be fast-tracked. ${ }^{24}$

- Although various wealth and inheritance and gift taxes would improve the progressivity of the tax system, there are serious administrative issues that raise the cost of collection too much. Countries with strong tax administrations can, however, consider this option for revenue enhancement. On the other hand, property taxation in several Asia and Pacific countries is underutilized as a revenue source. There is no reason it cannot be made more vigorous at the present juncture, even if levied by subnational governments.

- The pandemic has provided a boon to e-commerce. There is a corresponding need to modernize tax systems and administration systems to more effectively tax this mode of business.

- Excise taxes on 'sin goods' have traditionally been used for emergency revenue requirements and can continue to do so, subject to careful consideration of the undesirable consequences of these policies such as bootlegging, smuggling, and other criminal activities.

${ }^{23}$ A recent note by Mooij et al. (2020) reviews tax policy options in the post-COVID scenario in some detail.

24 The worldwide trend of falling corporate tax rates has already forced many countries to peg them at a lower level than they would prefer. In many cases, these low rates compared to personal income tax can facilitate tax avoidance/evasion of the latter tax through the formation of closely held corporations.

25 The G20/OECD initiative to limit base erosion and profit shifting (BEPS) is highly relevant in this context. 


\section{Appendix: Design of Stimuli in Selected Countries in the Asia and Pacific Region}

\begin{tabular}{|c|c|c|c|}
\hline Country & $\begin{array}{l}\text { Share of Fiscal } \\
\text { Support Provided } \\
\text { (as \% of GDP) }\end{array}$ & $\begin{array}{l}\text { Taxation } \\
\text { Measure }\end{array}$ & $\begin{array}{l}\text { Spending } \\
\text { Measure }\end{array}$ \\
\hline \multicolumn{4}{|c|}{ East Asia } \\
\hline $\begin{array}{l}\text { People's } \\
\text { Republic of } \\
\text { China }\end{array}$ & $4.50 \%$ of GDP & $\begin{array}{l}\text { Vat Exemptions: lifestyle } \\
\text { services, medical services, } \\
\text { catering and accommodation } \\
\text { services } \\
\text { Enhanced loss offset } \\
\text { provisions for seriously } \\
\text { affected businesses } \\
\text { Specific corporate income } \\
\text { tax incentives for health care } \\
\text { sector }\end{array}$ & $\begin{array}{l}\text { Increased expenditure on } \\
\text { pandemic prevention and } \\
\text { control } \\
\text { Spending on production } \\
\text { of medical and health } \\
\text { equipment } \\
\text { Payout of unemployment } \\
\text { insurance }\end{array}$ \\
\hline Japan & $\begin{array}{l}\text { First Package } \\
21 \% \text { of } 2019 \text { GDP } \\
\text { Second Package - } \\
21.1 \% \text { of } 2019 \text { GDP }\end{array}$ & $\begin{array}{l}\text { Tax payments and social } \\
\text { security contribution deferrals } \\
\text { Deadline extension for } \\
\text { personal income tax, gift tax, } \\
\text { and VAT return filing and } \\
\text { payment }\end{array}$ & $\begin{array}{l}\text { Cash handouts to every } \\
\text { individual }\end{array}$ \\
\hline \multicolumn{4}{|c|}{ South Asia } \\
\hline India & $\begin{array}{l}\text { Direct spending: } 1.7 \% \\
\text { of GDP } \\
\text { Foregone or deferred } \\
\text { revenue: } 0.3 \% \text { of } \\
\text { GDP } \\
\text { Below-the-line } \\
\text { measures designed to } \\
\text { support businesses } \\
\text { and shore up credit } \\
\text { provision to several } \\
\text { sectors: } 4.9 \% \text { of GDP }\end{array}$ & $\begin{array}{l}\text { Extension of return filing } \\
\text { deadline } \\
\text { Tax payment deferrals } \\
\text { relief from penalty and } \\
\text { prosecution } \\
\text { Tax filing extension for specific } \\
\text { businesses (annual turnover } \\
\text { less than ₹ } 50 \text { million) }\end{array}$ & $\begin{array}{l}\text { Direct spending ( } 1.7 \% \text { of } \\
\text { GDP). This includes in-kind } \\
\text { (food; cooking gas) and cash } \\
\text { transfers to low-income } \\
\text { households } \\
\text { Insurance coverage for workers } \\
\text { in the health care sector } \\
\text { Wage support and } \\
\text { employment provision } \\
\text { to low-wage workers }\end{array}$ \\
\hline Bangladesh & $1 \%$ of GDP & $\begin{array}{l}\text { Waivers on duties and } \\
\text { taxes on imports of medical } \\
\text { supplies, including protective } \\
\text { equipment and test kits }\end{array}$ & $\begin{array}{l}\text { Economic package for } \\
\text { exporting industries through } \\
\text { refinance mechanism } \\
\text { Health insurance for } \\
\text { government employees } \\
\text { most at risk }\end{array}$ \\
\hline
\end{tabular}


Table continued

\begin{tabular}{|c|c|c|c|}
\hline Country & $\begin{array}{c}\text { Share of Fiscal } \\
\text { Support Provided } \\
\text { (as \% of GDP) }\end{array}$ & $\begin{array}{l}\text { Taxation } \\
\text { Measure }\end{array}$ & $\begin{array}{l}\text { Spending } \\
\text { Measure }\end{array}$ \\
\hline \multicolumn{4}{|c|}{ Central West Asia } \\
\hline Uzbekistan & $2 \%$ of GDP & $\begin{array}{l}\text { Personal income tax payment } \\
\text { deferral } \\
\text { Personal income tax rate } \\
\text { reduction (by } 30 \% \text { ) for } \\
\text { individuals and entrepreneurs } \\
\text { in the tourism sector } \\
\text { Waiver on tourist tax }\end{array}$ & $\begin{array}{l}\text { Increased social benefits } \\
\text { for low-income families } \\
\text { Expanded funding } \\
\text { for health care }\end{array}$ \\
\hline Kazakhstan & Not Available & $\begin{array}{l}\text { Property tax reduced to } 0 \% \\
\text { for property used in affected } \\
\text { sectors such as tourism, } \\
\text { catering, and hotel sector } \\
\text { Deferral of all taxes and social } \\
\text { security contributions for } \\
\text { SMEs and microenterprises }\end{array}$ & $\begin{array}{l}\text { Cash payments to } \\
\text { the unemployed and } \\
\text { self-employed } \\
\text { Credit support to SMEs and } \\
\text { manufacturing enterprises }\end{array}$ \\
\hline \multicolumn{4}{|c|}{ Southeast Asia } \\
\hline Indonesia & $7 \%$ of GDP & $\begin{array}{l}\text { Tax relief for tourism sector } \\
\text { and individuals } \\
\text { Exemption for manufacturing } \\
\text { workers from income tax } \\
\text { Personal income tax } \\
\text { incentives for health care } \\
\text { workers } \\
\text { Permanent reductions of } \\
\text { the corporate income tax rate } \\
\text { from } 25 \% \text { to } 22 \% \text { in } \\
2020-2021 \text { and } 20 \% \text { starting } \\
\text { in } 2022\end{array}$ & $\begin{array}{l}\text { Conditional cash transfers, } \\
\text { and electricity subsidies } \\
\text { Expanded unemployment } \\
\text { benefits, including for workers } \\
\text { in the informal sector } \\
\text { Support to state-owned } \\
\text { enterprises in the form of } \\
\text { capital injections }\end{array}$ \\
\hline Singapore & $19.7 \%$ of GDP & Rebate in corporate tax & $\begin{array}{l}\text { Cash payout to all } \\
\text { Singaporeans } \\
\text { Wage subsidies }\end{array}$ \\
\hline
\end{tabular}


Table continued

\begin{tabular}{|c|c|c|c|}
\hline Country & $\begin{array}{l}\text { Share of Fiscal } \\
\text { Support Provided } \\
\text { (as \% of GDP) }\end{array}$ & $\begin{array}{l}\text { Taxation } \\
\text { Measure }\end{array}$ & $\begin{array}{l}\text { Spending } \\
\text { Measure }\end{array}$ \\
\hline \multicolumn{4}{|c|}{ Pacific } \\
\hline Australia & $14 \%$ of GDP & $\begin{array}{l}\text { Payroll tax relief for businesses } \\
\text { and relief for households }\end{array}$ & $\begin{array}{l}\text { Job keeper wage subsidies } \\
\text { Infrastructure expenditure } \\
\text { Home care package to } \\
\text { support senior citizens } \\
\text { Cash payments to vulnerable } \\
\text { households }\end{array}$ \\
\hline New Zealand & $19.5 \%$ of GDP & $\begin{array}{l}\text { Tax payment deferral for } \\
\text { businesses affected by } \\
\text { COVID-19 pandemic }\end{array}$ & $\begin{array}{l}\text { Health care-related spending } \\
\text { to reinforce capacity } \\
\text { Wage subsidy to support } \\
\text { employers } \\
\text { Income relief payments } \\
\text { Increase in social spending }\end{array}$ \\
\hline
\end{tabular}

COVID-19 = coronavirus disease, GDP = gross domestic product, SMEs = small and medium-sized enterprises Source: Compiled by the author based on information from OECD and IMF databases. 


\section{References}

B. Carrasco. 2020. We Need to Act Swiftly to Avoid Further Economic Damage from COVID-19. Asian Development Blog. 17 April. https://blogs.adb.org/-act-swiftly-to-avoidfurther-economic-damage-from-COVID-19.

Congressional Budget Office. 2008. Options for Responding to Short-Term Economic Weakness. Washington DC. Congressional Budget Office. https://www.cbo.gov/publication/41660.

F. D’Acunto, D. Hoang and M. Weber. 2020. Unconventional Fiscal Policy to Exit the COVID-19 Crisis. London: VOX ${ }^{\mathrm{EU}}$ Center for Economic Policy Research. 8 June. https://voxeu.org/article/unconventional-fiscalpolicy-exit-covid-19-crisis.

D.W. Elmendorf and J. Furman. 2008. If, When, How: A Primer on Fiscal Stimulus. The Hamilton Project Strategy Paper. Washington, DC: Brookings Institution. https://www.brookings. edu/research/if-when-how-a-primer-on-fiscalstimulus/.

Financial Times. 2020. Why the US Pandemic Response Risks Widening the Economic Divide. June 18. https://www.ft.com/content/d211f044ecf9-4531-91aa-b6f7815a98e3.

R. de Mooij et al. 2020. Tax Policy for Inclusive Growth after the Pandemic. International Monetary Fund. Special Series on COVID-19. https://www.imf.org/-/media/Files/Publications/ covid19-special-notes/en-special-series-oncovid-19-tax-policy-for-inclusive-growth-afterthe-pandemic.ashx.

P. Krugman. 2020. The Case for Permanent Stimulus. London: VOXEU Center for Economic Policy Research. https://voxeu.org/article/casepermanent-stimulus.
Organisation for Economic Co-operation and Development (OECD). 2020. "Tax Policy Database.” http://www.oecd.org/tax/tax-policy/ tax-database/. -2020. "Tax and Fiscal Policy in Response to the Coronavirus Crisis: Strengthening Confidence and Resilience." https://read. oecd-ilibrary.org/view/?ref=128_128575o6raktcOaa\&title=Tax-and-Fiscal-Policy-inResponse-to-the-Coronavirus-Crisis.

_n.d. Strategies for Aligning Stimulus Measures with Long Term Growth. https://www. oecd.org/economy/42555546.pdf.

International Monetary Fund. 2020. Policy Responses to Covid-19. https://www.imf.org/en/ Topics/imf-and-covid19/Policy-Responses-toCOVID-19\#J.

I. Steel and T. Harris. 2020. Covid-19 Economic Recovery: Fiscal Stimulus Choices for Lower-Income Countries. London: Overseas Development Institute. https://www.odi.org/sites/odi.org.uk/ files/resource-documents/fiscalstimulus_covid_ final.pdf.

Z. Zhang and Z Wenlang. 2009. The Road to Recovery: Fiscal Stimulus, Financial Sector Rehabilitation, and Potential Risks Ahead. Working Paper 18/2009. Hong Kong Monetary Authority. https://www.hkma.gov.hk/media/eng/ publication-and-research/research/workingpapers/HKMAWP09_18_full.pdf. 